5. Алімов В.І. Корозія та захист металів від корозії / В.І. Алімов, 3.А. Дурягіна. - ДонецькЛьвів : ТОВ «Східний видавничий дім», 2012. - 328 с.

6. (2015) Investigation of corrosion resistance welds metal hose made of steels AISI 304 and AISI 316 / N.A. Solidor, V.P. Ivanov, F.V. Morgay, B.I. Nosovsky // Eastern-European Journal of Enterprise Technologies. - 2015. - Vol. 76 (4/5). - Pp. 33-39. Mode of access : DOI: 10.15587/1729-4061.2015.47035.

Reviewer: V.I. Shchetinina

D.Sc. in Engineering, professor, SHEI «PSTU»

The article was admitted on 15.03.2020

UDC 621.762.4

doi: $10.31498 / 2225-6733.40 .2020 .216165$

(C) Abayev I.I."

\title{
WAYS OF INCREASING THE DENSITY, STRENGTH AND TRIBOTECHNICAL CHARACTERISTICS OF ANTIFRICTION POWDER COMPOSITIONS
}

The article considers the issues of obtaining high-density powder compositions by reducing the amount of process lubricant in the charge or its complete exclusion from the charge. It is shown that when technological grease is introduced into the charge under conditions of high pressing pressure, it prevents compaction of the powder charge. This is due to the negative effect of lubrication on the evacuation of air in the press. Lubrication enveloping the particles of metal powders at high sealing pressures closes the air outlets from the area of the compaction seal. In the case of applying grease to the die wall, the negative effect of lubrication at high pressing pressures is reduced to zero. The introduction of lubricant into the powder charge is justified only in the case of pushing the press out of the matrix, the lubricant reduces the pushing force. Reducing the amount of lubricant (zinc stearate) to a reasonable minimum at high compression pressures contributes to the compaction of the charge, i.e. $d \rho / d p$ remains a positive value. Experimental data show that the use of a minimum amount of lubricant helps to increase the density of the presses, and hence all the mechanical properties of the sintered powder compositions. To increase the competitiveness of powder compositions with cast materials of similar composition, it is necessary to use the technology of double pressing and sintering. However, double pressing technology doubles the product production cycle. Therefore, further extensive research is required to fully solve the problem of obtaining non-porous powder compositions by single pressing and sintering.

Keywords: density, strength, tribotechnical characteristics, powder composition, compaction pressure, the lubricant, the sealing performance.

Абаєв І.І. Шляхи підвищення щільності, міцності та триботехнічних характеристик антифрикційних порошкових композицій. $У$ статті розглядаються питання отримання високоплотних порошкових композицій шляхом зниження кількості технологічного мастила в шихті або повного виключення ї̈ з иихти. Показано, щя при введенні в шихту технологічного мастила в умовах положення високого тиску пресування, вона перешкоджає ущільненню порошкової шихти. Це пояснюється негативним впливом мастила на евакуацію повітря, щзо знаходиться в порошку. Мастило, огортаючи частки металевих порошків при високому тиску ущільнення, закриває шляхи виходу повітря з області ущільнення пресування. У разі

\footnotetext{
*applicant, Azerbaijan Technical University, Baku, Azerbaijan, irmik.abayev@gmail.com
} 


\title{
p-ISSN: 2225-6733; e-ISSN: 2519-271X
}

нанесення мастила на стінку матриці негативний вплив мастила при високому тиску пресування зводиться до нуля. Введення мастила в порошкову шихту виправдано тільки в разі виштовхування пресування з матриці, мастило знижує зусилля виштовхування. Зниження кількості мастила (стеарата ичнку) до розумного мінімуму при високих тисках пресування сприяе ущільненню шихти, тобто $d \rho / d p$ залишається позитивною величиною. Експериментальні дані показують, щзо використання мінімальної кількості мастила сприяе підвищенню щільності прессовок, а отже і всіх механічних властивостей спечених порошкових композицій. Для підвищення конкурентоспроможності порошкових композицій литими матеріалами аналогічного складу необхідне застосування технології подвійного пресування і спікання. Однак технологія подвійного пресування вдвічі збільшує ицикл виробництва виробів. Тому для повночінного вирімення питання отримання беспорістих порошкових композицій одноразовим пресуванням і спіканням потрібні подальші численні дослідження.

Ключові слова: щұільність, міцність, триботехнічні характеристики, порошкова композиція, тиск пресування, мастило, ефективність ущџільнення.

\begin{abstract}
Абаев И.И. Пути повышения плотности, прочностных и триботехнических характеристик антифрикционных порошковых композиций. $B$ статье рассматриваются вопросы получения высокоплотных порошковых композиций путем снижения количества технологической смазки в шихте или полного исключения ее из шихты. Показано что при введении в шихту технологической смазки в условиях положения высокого давления прессования она препятствует уплотнению порошковой шихты. Это объясняется отрицательным влиянием смазки на эвакуацию воздуха, находящегося в порошке. Смазка, обволакивая частищы металлических порошков при высоких давлениях уплотнения, закрывает пути выхода воздуха из области уплотнения прессовки. В случае нанесения смазки на стенку матрицы отрицательное влияние смазки при высоких давлениях прессования сводится к нулю. Введение смазки в порошковую шихту оправдано только в случае выталкивания прессовки из матрищы, смазка снижает усилия выталкивания. Снижение количества смазки (стеарата иинка) до разумного минимума при высоких давлениях прессования способствует уплотнению шихты, то есть $d \rho / d p$ остается положительной величиной. Экспериментальные данные показывают, что использование минимального количества смазки способствует повышению плотности прессовок, а, следовательно, и всех механических свойств спеченных порошковых композииий. Для повышения конкурентоспособности порошковых композиций литыли материалами аналогичного состава необходимо применение технологии двойного прессования и спекания. Однако технология двойного прессования вдвое увеличивает иикл производства изделий. Поэтому для полноченного решения вопроса получения беспористых порошковых композиций однократным прессованием и спеканием требуются дальнейшие обширные исследования.
\end{abstract}

Ключевые слова: плотность, прочность, триботехнические характеристики, порошковая композиция, давление прессования, смазка, эффективность уплотнения.

Description of the problem. The process of preparing high density powdered materials by the method of single-stage cold pressing and sintering is closely related to the presence of low density (less than $1.0 \mathrm{~g} / \mathrm{cm}^{3}$ ) organic grease in the charge and which are incompressible even when they are introduced in small quantities. Therewith a sufficiently large part of pressing volume, which remains after degreasing in the form of pores, is accounted for the part of grease [1,2].

Analysis of recent research and publications. The strength and the volume of bearing capacity of powdered materials largely depend on the density of materials. In order to increase the density of powdered compositionseither double pressing or hot pressing it is used. However the technologies of doubled pressing-sintering as well as static and dynamic hot pressing of porous work materials have labour and energy intensity in comparison with the technology of the single-stage pressing and sintering. 


\section{p-ISSN: 2225-6733; e-ISSN: 2519-271X}

In this context the potentialities of the single-stage pressing and sintering in terms of increasing of compositions density are not exhausted. The main emphasis of the researches is on the increasing pressed density through the excessive increase of forging pressure which is not undesirable due to a decrease in the resistance of mold tools and an increase in the energy intensity of the process.

Searching of other ways of problem solution is still important for today.

Purpose of the article - is to increase the strength and tribotechnical characteristics of powdered compositions by using the rational amount of technological grease in a powdered charge.

Presentation of the main material. Figure 1 shows a diagram of critical forging pressure $\left(P_{k}\right)$ where the grease has a negative effect on the compression rate of the powder, since it is higher than this pressure and makes it difficult to obtain high-density products [1]. Hence, with the increase of the grease content in a charge $\mathrm{P}_{\mathrm{k}}$ will decrease even more.

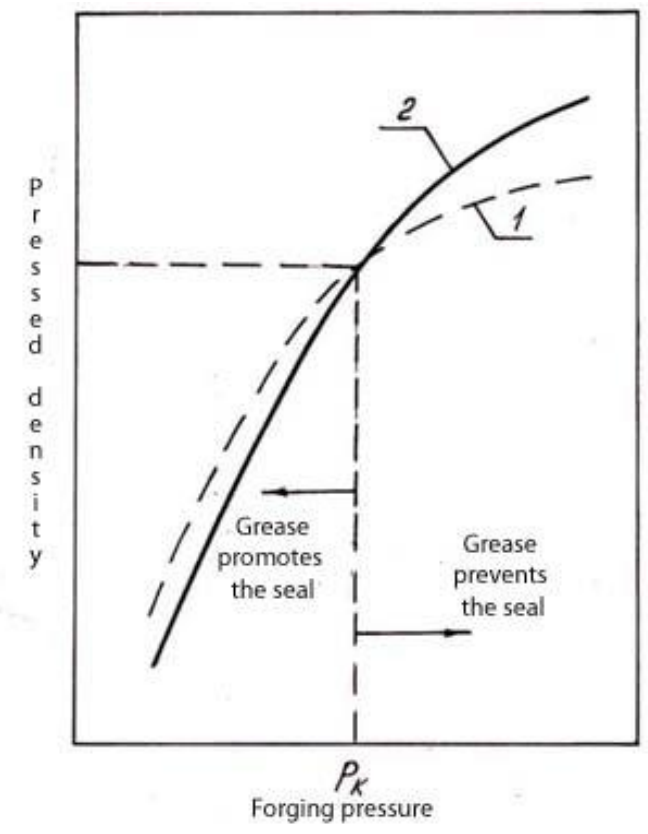

Fig. 1 - The grease effect on powder compaction: 1 - the grease is added to the powder; 2 - the grease is applied on the matrix walls

In order to eliminate the negative effect of the grease volume it is possible to apply it on the matrix walls. However at present there are no any engineering decisions that can provide an automatic applying of the grease on the matrix walls under conditions of industrial production.

Alternative decision to this problem is the application of a tool (especially matrices) made of materials that do not need any grease, for example ceramic tools. But the problems connected with the manufacturing of such tools have not yet been solved and it will take time to bring the strength of ceramic matrices to the necessary level.

The other aspects of work on this problem is the use of more dense grease than organic ones in the form of plastic metals and non-metallic inclusions such as copper, tin and graphite. The attractive thing about them is that they can be added in large amount and there is no need to remove them before sintering. Satisfactory results in decreasing of ejection force and good quality of a molding surface are achieved by their use in a charge in an abnormally high amount, which leads to a significant change in the chemical composition of the powdered material [2].

However the introduction of plastic nonferrous metals and alloys to the charge significantly increases a prime cost of materials, which is not always allowable in manufacturing. The other not the least of the factors is low wear resisting properties of such materials under the condition of boundary and dry friction.

The author [1] has found out that it is possible to achieve the maximum pressed density with the low ejection force and satisfactory quality of the surface if stearic acid is used as a lubricant. This acid was introduced to the charge of iron powder ASC100.29 in the amount of 0,2 wt.\%. 


\section{p-ISSN: 2225-6733; e-ISSN: 2519-271X}

Figure 2 shows the density relation and mechanical properties of iron powder samples, which contain $0,25 \mathrm{wt} . \%$ zinc stearate and which are sintered at temperature of 1120 and $1250^{\circ} \mathrm{C}$ of forging pressure and we can see on this Figure, that the sealing efficiency of material $(d \rho / d p)$ still remains positive value even at high pressures. As the forging pressure increases, all the mechanical properties of the material increase, but the plastic properties are significantly improved $(\mathrm{KC}, \delta)$.
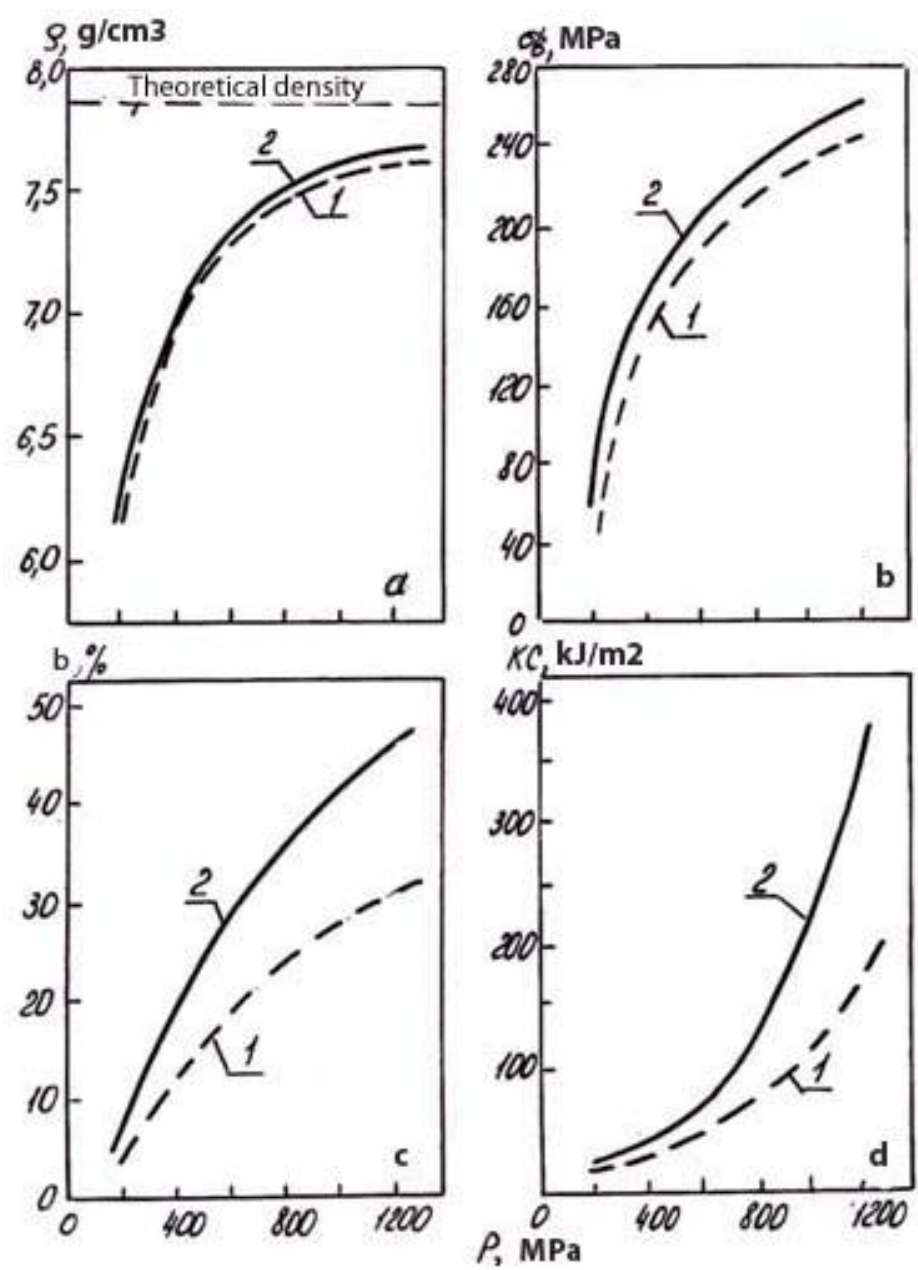

Fig. 2 - Dependence of density and mechanical properties of iron powder samples sintered at various conditions $-1120^{\circ} \mathrm{C}, 1 \mathrm{~h}(1)$ and $1250^{\circ} \mathrm{C}, 2 \mathrm{~h}(2)$ - forging pressure: a $-\rho$; $\mathrm{b}-\mathrm{F}_{\mathrm{tu}} ; \mathrm{c}-\delta ; \mathrm{d}-\mathrm{KC}$

Similar experiments were performed with iron-copper alloys and Astaloy A from prealloyed powders, that are very difficult to press, as well as unalloyed and alloyed carbon steels. The results of the experiments are given in table 1 and show that charge pressing with minimal quantity of technological grease $(0,25 \mathrm{wt} . \%)$ at high pressure leads to increase of density in all cases as well as the mechanical properties and especially Astaloy A alloy.

Figure 3 shows the properties of sintered and casted materials, obtained by using various modes. The properties of sintered iron, pressed at high pressure are comparable to the properties of technically ingot iron, while the properties of high density steel powder are a little bit worse than forged ones, but they significantly exceed the properties of common sintered steels.

It is possible to achieve the further improvement of mechanical properties by applying of high pressure when repressing of sintered bars (tables 1,2 and Figure 3). The mechanical properties of steels obtained by double pressing and sintering are equal to the properties of casted and wrought steels. Comparatively slight reduction of the residual porosity provides significant increase in the plastic properties of powdered products. However the technology of doubled pressing-sintering doubles the production cycle under conditions of increased operational costs. 
Table 1

Mechanical properties of iron-based powdered materials

\begin{tabular}{|c|c|c|c|c|c|c|c|}
\hline Material & $\mathrm{P}, \mathrm{MPa}$ & $\begin{array}{l}\text { Sintering condi- } \\
\text { tions: } \\
\tau, \mathrm{r} \text { and } \mathrm{T},{ }^{\circ} \mathrm{C}\end{array}$ & $\begin{array}{c}\rho, \\
\mathrm{g} / \mathrm{cm}^{3}\end{array}$ & $\begin{array}{l}\mathrm{F}_{\mathrm{tu}}, \\
\mathrm{MPa}\end{array}$ & $\begin{array}{l}\sigma_{0,2} \\
\mathrm{MPa}\end{array}$ & $\delta, \%$ & $\mathrm{KC}, \mathrm{kJ} / \mathrm{m}^{2}$ \\
\hline \multirow{4}{*}{$\mathrm{Fe}-3 \% \mathrm{C}$} & \multirow{2}{*}{600} & $2 ; 1120$ & 7,2 & 329 & 280 & 5,2 & 18,7 \\
\hline & & $2 ; 1200$ & 7,18 & 395 & 326 & 7,2 & 318 \\
\hline & \multirow{2}{*}{1200} & $2 ; 1120$ & 7,48 & 389 & 315 & 10,5 & 408 \\
\hline & & $2 ; 1250$ & 7,48 & 427 & 353 & 13,8 & 770 \\
\hline \multirow{4}{*}{ Astaloy A } & \multirow{2}{*}{600} & 0,$5 ; 1250$ & 7,15 & 361 & 162 & 8,0 & 62 \\
\hline & & $4 ; 1250$ & 7,15 & 270 & 156 & 11,0 & 109 \\
\hline & \multirow{2}{*}{1200} & 0,$5 ; 1250$ & 7,67 & 366 & 236 & 11,7 & 150 \\
\hline & & $4 ; 1250$ & 7,66 & 327 & 188 & 15,3 & 257 \\
\hline \multirow{4}{*}{$\mathrm{Fe}-0,5 \% \mathrm{C}$} & \multirow[t]{2}{*}{600} & $1 ; 1100$ & 7,20 & 376 & not under- & 5,7 & not under- \\
\hline & & $1 ; 1200$ & 7,21 & 476 & stood $\langle--\rangle\rangle$ & 5,8 & stood $\langle--\rangle\rangle$ \\
\hline & \multirow{2}{*}{1000} & $1 ; 1100$ & 7,43 & 426 & $\langle(--\rangle\rangle$ & 6,6 & 《---» \\
\hline & & $1 ; 1200$ & 7,44 & 523 & «--» & 8,8 & $\langle(--\rangle$ \\
\hline \multirow{4}{*}{$\begin{array}{l}\mathrm{Fe}-2 \%- \\
0,5 \% \mathrm{C}\end{array}$} & \multirow{2}{*}{600} & $1 ; 1100$ & 7,18 & 579 & $\langle\ll--\rangle$ & 5,0 & $\langle\langle--\rangle$ \\
\hline & & $1 ; 1200$ & 7,19 & 607 & «--»» & 3,2 & $\langle(--\rangle$ \\
\hline & \multirow{2}{*}{1000} & $1 ; 1100$ & 7,41 & 645 & 《---» & 5,0 & $\langle--\rangle$ \\
\hline & & $1 ; 1200$ & 7,41 & 739 & $\langle--\rangle\rangle$ & 5,4 & $\langle--\rangle\rangle$ \\
\hline \multirow{2}{*}{$\begin{array}{c}\mathrm{Fe}-1 \% \\
\mathrm{Mo}-0,7 \% \mathrm{C}\end{array}$} & 1000 & $1 ; 1250$ & 7,41 & 685 & $\langle(--\rangle$ & 5,0 & 380 \\
\hline & $600+1000$ & $1 ; 1250$ & 7,55 & 775 & $\langle\ll--\rangle$ & 6,5 & 1020 \\
\hline \multirow{2}{*}{$\begin{array}{c}\text { Fe- } 1,5 \% \\
\mathrm{Mo}-0,7 \% \mathrm{C}\end{array}$} & 1000 & $1 ; 1250$ & 7,87 & 720 & «---» & 4,5 & 450 \\
\hline & $600+1000$ & $1 ; 1250$ & 7,56 & 805 & $\langle\langle--\rangle$ & 6,2 & 1110 \\
\hline \multirow{2}{*}{$\begin{array}{c}\mathrm{Fe}-2 \% \\
\mathrm{Cr}-0,7 \%\end{array}$} & 1000 & $1 ; 1250$ & 7,28 & 720 & $\langle\langle--\rangle$ & 3,5 & 200 \\
\hline & $600+1000$ & $1 ; 1250$ & 7,41 & 835 & $\langle--\rangle$ & 6,8 & 230 \\
\hline
\end{tabular}

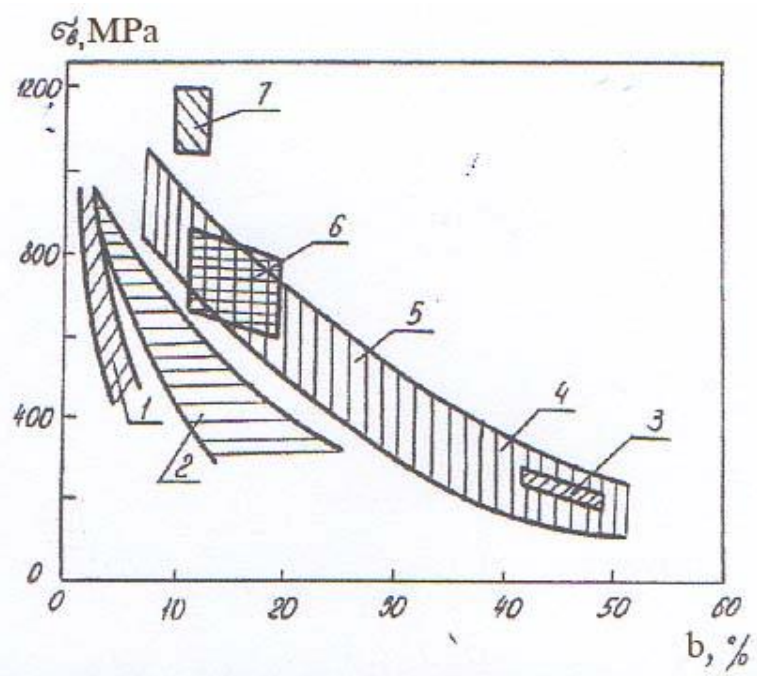

Fig. 3 - Mechanical properties of iron-based materials: 1 - common porous steel; 2 - sintered materials $\mathrm{Fe}-\mathrm{C}$ and $\mathrm{Fe}-\mathrm{Cu}-\mathrm{C}$, pressed at high pressure; 3 - sintered iron pressed at high pressure; 4 - technically ingot iron; 5 - casted and forged steels; 6 - sintered material Fe-C, obtained by double pressing; 7 - high resistance steel

It is worth pointing out that the problem of increasing of density and strength properties of powdered materials by the authors [2-4] was not considered in a comprehensive manner and it was also not detailed the reasons that lead to decrease in possibilities of technology of single-stage pressing-sintering. In particular, it is not taken into account the influence of the conditions for draining gases from molds during pressing process, depending on a number of factors: granulometric texture and 


\section{p-ISSN: 2225-6733; e-ISSN: 2519-271X}

powders morphology, content of grease in the charge, the quality and construction of work elements of the mold, pressing and sintering conditions, etc. on density and strength properties of sintered materials. Besides it was not proposed the technical solution, which provides the charge cold pressing without technological grease.

Table 2

Mechanical properties of carbon steels obtained by double pressing*

\begin{tabular}{|c|c|c|c|c|}
\hline Material & $\begin{array}{c}\text { Sintering conditions: } \\
\tau, \mathrm{r} \text { and T, }{ }^{\circ} \mathrm{C}\end{array}$ & $\begin{array}{c}\rho, \\
\mathrm{g} / \mathrm{cm}^{3}\end{array}$ & $\begin{array}{c}\mathrm{F}_{\mathrm{tu}}, \\
\mathrm{MPa}\end{array}$ & $\delta, \%$ \\
\hline \multirow{3}{*}{$\mathrm{Fe}-0,5 \%$} & $1 ; 1100$ & 7,56 & 527 & 13,2 \\
& $2 ; 1100$ & 7,56 & 559 & 12,5 \\
& $1 ; 1200$ & 7,58 & 499 & 18,5 \\
$\mathrm{Fe}-0,7 \%$ & $2 ; 1200$ & 7,58 & 508 & 24,0 \\
& $1 ; 1100$ & 7,50 & 683 & 10,1 \\
& $2 ; 1100$ & 7,51 & 7,34 & 19,7 \\
& $1 ; 1200$ & 7,52 & 747 & 12,4 \\
\hline
\end{tabular}

* - compression at $600 \mathrm{MPa}$, annealing during 1 hour at $650^{\circ} \mathrm{C}$, recompression at $1200 \mathrm{MPa}$, sintering.

For this reason in order to obtain high density and therefore strong powder compositions, it is necessary to develop new approaches and techniques for cold pressing of powder charges. So upon that, exclusion of a technological charge from the charge may be the most attractive approach and thereby achievement of active air drainage from the matrix area when compaction of press powder. Further studies in this area can be considered as the most promising ones.

\section{Conclusion}

It was established that the potentialities of cold pressing of powdered metal charges in order to increase the density and hence the properties have not been exhausted. For comprehensive solution of this issue it is necessary extensive studies of the compaction processes of plastic and elastoplastic charges for determination of decompaction of bars both when compression and sintering processes.

\section{References:}

1. Mamedov A.T. Vliianie stearata tsinka na fizicheskie svoistva poroshkovykh materialov [Effect of zinc stearate on the physical properties of powder materials]. Doklady AN Azerb. SSR-Reports of AS Azerb. SSR, 1990, no. 9, pp. 23-25. (Rus.)

2. Mamedov A.T. Vliianie stearata tsinka na mekhanicheskie svoistva poroshkov [Effect of zinc stearate on the mechanical properties of powders]. Doklady AN Azerb. SSR - Reports of AS Azerb. SSR, 1991, no. 10, pp. 14-18. (Rus.)

3. Dorofeev B.G., Geidarov V.A., Mamedov A.T. Osobennosti polucheniia poroshkovykh materialov konstruktsionnogo i antifriktsionnogo naznacheniia [Features of obtaining powder materials for structural and antifriction purposes]. Poroshkovaia metallurgiia - Powder Metallurgy, 1987, no. 9, pp. 42-47. (Rus.)

4. Geidarov V.A. Struktura i svoistva iznosostoikikh poroshkovykh materialov dlia bytovykh konditsionerov $i$ optimizatsiia parametrov ikh polucheniia. Diss. kand. techn. nauk [Structure and properties of wear-resistant powder materials for household air conditioners and optimization of the parameters for their production. Cand. tech. sci. diss.]. Novocherkassk, 1986. - 203 p. (Rus.)

\section{Перелік використаних джерел:}

1. Мамедов А.Т. Влияние стеарата цинка на физические свойства порошковых материалов / А.Т. Мамедов // Доклады АН Азерб. ССР. - 1990. - № 9. - С. 23-25.

2. Мамедов А.Т. Влияние стеарата цинка на механические свойства порошков / А.Т. Мамедов // Доклады АН Азерб. ССР. - 1991. - № 10. - С. 14-18.

3. Дорофеев Б.Г., Гейдаров В.А., Мамедов А.Т. Особенности получения порошковых матери- 
алов конструкционного и антифрикционного назначения / Б.Г. Дорофеев, В.А. Гейдаров, А.Т. Мамедов // Порошковая металлургия. - 1987. - № 9. - С. 42-47.

4. Гейдаров В.А. Структура и свойства износостойких порошковых материалов для бытовых кондиционеров и оптимизация параметров их получения : дис. ... канд. техн. наук : 05.16 .09 / Гейдаров Вагиф Абас оглы - Новочеркасск, 1986. - 203 с.

Reviewer: N.Sh. Ismayilov

$\mathrm{PhD}$ in Engineering, a professor, Azerbaijan Technical University

The article was admitted on 05.03.2020

УДК 621.798.927

doi: 10.31498/2225-6733.40.2020.216166

(C) Роянов B.O. ${ }^{1}$, Захарова I.B. ${ }^{2}$

\section{ЗАСТОСУВАННЯ МЕТОДУ ЕЛЕКТРОДУГОВОЇ МЕТАЛІЗАЦЇ 3 ПУЛЬСУЮЧИМ ПОВІТРЯНО-РОЗПИЛЮВАЛЬНИМ СТРУМЕНЕМ ДЛЯ НАНЕСЕННЯ ПОКРИТТІВ 3 ПОРОШКОВОГО ДРОТУ}

3 метою зниження окисного впливу розпилювального струменя на рідкий метал ториів, які плавляться, раніше запропонований і розроблений спосіб періодичного (пульсуючого) впливу на рідкий метал електродів повітряного розпилювального струменя з урахуванням того, щуо пауза між моментами дї потоку дозволяє забезпечити плавлення електродів з обмеженим обсягом повітря. Представлено пристрій, розроблений таким чином, щзо забезпечує отримання пульсаиій потоку з різною частотою і тривалістю, отримані дані про вплив пульсуючого потоку на технологічні характеристики покриттів, зокрема, значне зниження втрат легуючих елементів. В якості вирішення проблеми енергозбереження при дуговій металізаиії розглянуто питання про використання кисню повітряного розпилювального струменя з метою отримання зносостійких покриттів з високою міцністю зчеплення за рахунок утворення твердих оксидів з недефіцитних порошків металів $i$ сплавів. Зважаючи на обмежений діапазон складів дротів суцільного перетину, запропоновано застосування порошкових дротів, шуо складаються з маловуглецевої оболонки і стрижня з недефіцитних, поширених порошків металів $і$ феросплавів, щзо забезпечують отримання високо зносостійких покриттів з підвищеною міцністю зчеплення. В якості досліджуваного було взято економно-легований порошковий дріт ПП-ММ-2, розроблений на кафедрі автоматизаичї та механізаичї зварювального виробництва Приазовського державного технічного університету. У даній роботі розглядається вплив частоти пульсачій розпилювального потоку повітря при дуговій металізацї на мікроструктуру $і$ величину мікротвердості покриттів, отриманих шляхом застосування порошкових дротів.

Ключові слова: дугова металізація, порочковий дріт, легуючі елементи, карбіди, розпилювальний потік, частота пульсацій, покриття, мікротвердість, мікроструктура.

Роянов В.А., Захарова И.В. Применение метода электродуговой металлизации с пульсирующей воздушно-распьляющей струей для нанесения покрытий из порошковой проволоки. С целью снижения окислительного воздействия распьляю-

\footnotetext{
${ }^{1}$ д-р техн. наук, професор, ДВНЗ «Приазовський державний технічний університет», м. Маріуполь, ORCID:0000-0002-0899-173X

2 канд. техн. наук, дочент, ДВНЗ «Приазовський державний технічний університет», м. Маріуполь, ORCID:0000-0002-3492-0134, zakharovaiv75@gmail.com
} 